\title{
Survey Kepuasan Mahasiswa Atas Layanan Manajemen Pendidikan di STKIP Muhammadiyah Bogor Tahun 2020
}

\author{
Dadan Samsul Badar, Wawan Karsiwan \\ STKIP Muhammadiyah Bogor \\ e-mail : dadansamsulbadar@yahoo.com
}

\begin{abstract}
The survey of student satisfaction about education management services was conducted to evaluate the level of student satisfaction about education management services that have been carried out by STKIP Muhammadiyah Bogor. The purpose of this survey is to evaluate and plan to improve the quality of institutional services for students. Students as the main customers of education need to get priority in education management services. This study uses a quantitative approach using survey techniques and data processed through simple statistics in the form of percentages. The survey was conducted on 75 students representing four existing study programs by measuring six indicators of education management services consisting of: curriculum, education personnel, finance, infrastructure, academic and financial administration services. The survey results shows that, on curriculum indicators there still $17 \%$ of students very dissatisfied and dissatisfied. On the indicator of teaching staff (Lecturers) there still 5\% of students were dissatisfied, about 53\% of students were dissatisfied of infrastructur and 13\% were very dissatisfied, there were about 30\% dissatisfied and 3\% were very dissatisfied, and the last indicator of academic and financial administration services, there were 25\% dissatisfied and $7 \%$ very dissatisfied. the survey shows that the indicators of compliance with infrastructure facilities are high, so it is necessary to get priority in a gradual and continuous service development program which is then followed by financial aspects, curriculum and teaching staff.
\end{abstract}

Keywords: Student satisfaction, education management, management services

\begin{abstract}
ABSTRAK
Survey kepuasan mahasiswa atas layanan manajemen pendidikan ini dilakukan untuk melakukan evaluasi tingkat kepuasan mahasiswa atas layanan manajemen pendidikan yang telah dilakukan oleh STKIP Muhammadiyah Bogor. Tujuan dari survei ini adalah untuk melakukan evaluasi dan merencanakan program peningkatan mutu layanan lembaga terhadap mahasiswa. Hal ini, penting dilakukan dimana mahasiswa sebagai pelanggan utama pendidikan perlu mendapat prioritas dalam layanan manajemen pendidikan. Penelitian ini menggunakan pendekatan kuantitatif dengan menggunakan teknik survey dan pengolahan data dilakukan melalui statistik sederhana berupa prosentase. Survey dilakukan terhadap 75 mahasiswa mewakili empat program studi yang ada dengan mengukur enam indikator layanan manajemen pendidikan yang terdiri dari: Kurikulum, Tenaga Pendidikan, Keuangan, Sarana Prasarana, Layanan administrasi akademik dan keuangan. Hasil survey menunjukkan bahwa, pada indikator kurikulum masih terdapat 17\% mahasiswa yang menyatakan masih sangat tidak puas dan tidak puas, pada indikator tenaga pendidik (Dosen) masih terdapat sebesar 5\% mahasiswa menyatakan tidak puas, indikator Sarana Prasarana masih terdapat mahasiswa sebesar 53\% menyatakan tidak puas dan 13\% menyatakan sangat tidak puas, Indikator keuangan masih terdapat mahasiswa sebesar 30\% menyatakan tidak puas dan 3\% menyatakan sangat tidak puas, dan indikator terakhir layanan administrasi akademik dan keuangan, masih terdapat mahasiswa sebesar 25\% menyatakan tidak puas dan 7\% menyatakan sangat tidak puas. Dari hasil survey tersebut, nampak pada indikator pemenuhan sarana prasarana masih sangat tinggi, sehingga perlu mendapat prioritas dalam program pengembangan layanan secara bertahap dan berkelanjutan yang selanjutnya diikuti oleh aspek keuangan, kurikulum dan tenaga pendidik
\end{abstract}

Kata kunci: kepuasan mahasiswa, manajemen pendidikan, manajemen pelayanan

Submitted Feb 20, 2021 | Revised Mar 07, 2021 | Accepted Mar 10, 2021

\section{Pendahuluan}

Pelayanan merupakan bagian yang sangat penting dalam kegiatan semua organisasi terlebih yang bergerak di sektor jasa. Pelayanan yang baik akan mendukung terhadap penciptaan kepuasan konsumen dan ujungnya berimplikasi terhadap kemajuan organisasi yang bersangkutan. 
Kepuasan konsumen sebagai implikasi dari maksimalisasi pelayanan sudah banyak diteliti sebelumnya baik dalam perusahaan jasa maupun non jasa. Diantaranya bidang perbankan oleh Yulian Belinda Rahmawati tahun 2016, real estate oleh Wirdayani Wahab tahun 2019, industri pariwisata oleh Priska R.E. Mamesah tahun 2020, Putri Ronitawati dan, Desi W.T. Simangunsong tahun 2016.

Dalam bidang jasa pendidikan tinggi, penelitian yang mengupas tentang pengaruh pelayanan terhadap kepuasan konsumen sudah banyak diteliti diantaranya yang dilakukan oleh Erika Budiarti tahun 2018 dengan judul Pengaruh Kualitas Layanan, Budaya Akademik, dan Citra Lembaga Terhadap Kepuasan Mahasiswa, kemudian penelitian yang dilakukan oleh Faizan Ali, Yuan Zhou, Kashif Hussain, Pradeep Kumar Nair, Neethiahnanthan Ari Ragavan tahun 2016 dengan judul Satisfaction, Image And Loyalty? A Study Of International Students In Malaysian Public Universities. Untuk lingkup emerging country, penelitian dilakukan diantaranya oleh Md. Mahi Uddin, Kalsom Ali, Mohammad Aktaruzzaman Khan yang dilakukan tahun 2018 dengan judul Impact Of Service Quality (Sq) On Student Satisfaction: Empirical Evidence In The Higher Education Context Of Emerging Economy. Hampir keseluruhannya menunjukan adanya pengeruh antara kualitas pelayanan dengan kepuasan konsumen.

Prinsip utama dari kepuasan konsumen adalah memberikan yang terbaik kepada konsumen sesuai dengan apa yang diinginkannya, sehingga diperlukan upaya peningkatan kualitas layanan yang disesuaikan dengan harapan konsumen.

Dalam dunita Pendidikan Tinggi (PT), kepuasan mahasiswa dianggap sebagai alat yang vital dalam menilai kualitas layanan sebuah PT sebagaimana diungkapakan oleh Jalal R. M. Hanaysha, Haim Hilman Abdullah and Ari Warokka. 2011. Dalam penelitian berjudul Service Quality and Students' Satisfaction at Higher Learning Institutions: The Competing Dimensions of Malaysian Universities' Competitiveness, Journal of Southeast Asian. hal ini karena PT sudah masuk dalam katagori sektor yang kompetitif sebagaimana disebutkan oleh Suh Li Phang, dalam Factors influencing international students' study destination decision abroad, Thesis: University of Gothenburg (Gothenburg: Sweden, 2013). Dimana selayaknya hukum penawaran dan permintaan yang selama ini dianut oleh dunia perekonomian ternyata mulai berlaku juga untuk dunia pendidikan. PT saat ini mulai bersaing untuk mendapatkan calon mahasiswa dimana salah satunya dengan menonjolkan keunggulan-keunggulan yang dimiliki kepada konsumen dalam hal ini mahasiswa dan calon mahasiswa. Salah satu keunggulan yang bisa ditampilkan adalah pelayanan manajemen.

Kitchroen dalam penelitiannya berjudul Service Quality in Educational Institusions menegaskan bahwa kualitas pelayanan yang buruk akan berpengaruh terhadap sektor pendanaan dan kelangsungan hidup universitas melalui penurunan popularitas institusi dan penurunan jumlah dan standar pendaftar, meskipun dampak tersebut terjadi secara tidak langsung dan dalam jangka waktu yang lama.

Sekolah Tinggi Keguruan dan Ilmu Pendidikan Muhammadiyah Bogor merupakan sebuah lembaga pendidikan tinggi yang berdiri di daerah bogor barat. Meski tidak berlokasi di kota, tapi persaingan tidaklah bisa dianggap mudah. Untuk itu STKIPMB perlu untuk selalu memperbaiki diri terutama dari sisi kinerja pelayanan kepada mahasiswa agar penilaian pasar terus semakin membaik. Hal ini tidak lepas dari ketatnya persaingan antar PT terutama yang berlokasi di bogor. Jumlah PTS di bogor ada setidaknya 6 buah dan masih ada lagi yang sedang dalam proses pendirian. Hal ini tentu akan semakin menambah ketatnya persaingan dalam memperoleh calon mahasiswa.

Dalam penelitian yang dilakukan oleh Krisana Kitchroen dalam Literatur Review: Service Quality in Educational Institusions. (ABAC Journal. 2004), Vol. 24, dikatakan bahwa kualitas pelayanan yang dirasakan mahasiswa menjadi salah satu faktor penentu kesuksesan sebuah PT. Mahasiswa sebagai pengguna utama PT menjadi salah satu penentu hidup matinya sebuah PT. Kepuasan itu bisa menumbuhkan loyalitas dan kebanggaan dihati mahasiswa yang lebih jauhnya akan mendorong kesiapan mereka menjadi agen-agen pemasaran bagi kampus tersebut. 
Untuk alasan tersebut, kemudian menjadi penting untuk mengetahui sejauh mana kepuasan yang dirasakan oleh para mahasiswa di STKIP Muhammadiyah Bogor dalam hal pelayanan yang diberikan oleh pihak kampus, sehingga bisa didapatkan gambaran seberapa perlu pihak mamajemen untuk memperbaiki sistem pelayanannya, dan untuk mengetahui bagian-bagian mana dari sistem tersebut yang dirasa masih belum memberikan pelayanan yang memuaskan bagi para mahasiswa.

\section{Metode Penelitian}

Pendekatan penelitian yang digunakan dalam penelitian ini adalah pendekatan kuantitatif dengan metode survey yang digunakan. Sampel penelitian yang menjadi sasaran survey berjumlah 75 mahasiswa mewakili empat program studi yang ada di STKIP Muhammadiyah Bogor. Sebagaimana, dinyatakan bahwa metode survey merupakan salah satu metode penelitian kuantitatif yang bertujuan untuk melihat keadaan yang menjadi objek penelitian apa adanya, dengan melihat data dan informasi yang ada dalam sampel, tanpa memberikan perlakuan khusus (Indrawan, 2016). Teknik pengumpulan data yang digunakan berupa angket online berupa Google Form yang disebar melalui WAG Mahasiswa. Sementara analisis data digunakan teknik prosentase sederhana.

\section{Hasil dan Pembahasan}

Hasil penelitian ini diuraikan hasil survey kepuasan mahasiswa atas layanan manajemen kampus dengan lima aspek indikator yang diukur terdiri dari : Kurikulum, Tenaga Pendidik (Dosen), Sarana Prasarana, Keuangan, dan layanan administrasi akademik dan keuangan.

1. Kurikulum

Pada aspek kurikulum masih terdapat mahasiswa STKIP Muhammadiyah Bogor yang merasa tidak puas sebesar 17\% ( Tidak Puas dan Sangat Tidak Puas), sementara mahasiswa yang sudah merasa puas sebesar 83\% (Puas dan Sangat Puas), Pengetahuan dan Keterampilan yang di dapat dalam perkuliahan (13 Responden). Beberapa indikator yang masih harus ditingkatkan pada aspek-aspek Kurikulum berupa: Kebijakan Kurikulum (12 Responden), kurikulum yang bisa memenuhi kebutuhan masyarakat dan dunia kerja (16 Responden), Waktu Perkuliahan (24 Responden), Jumlah Beban SKS Pembelajaran (12 Responden).
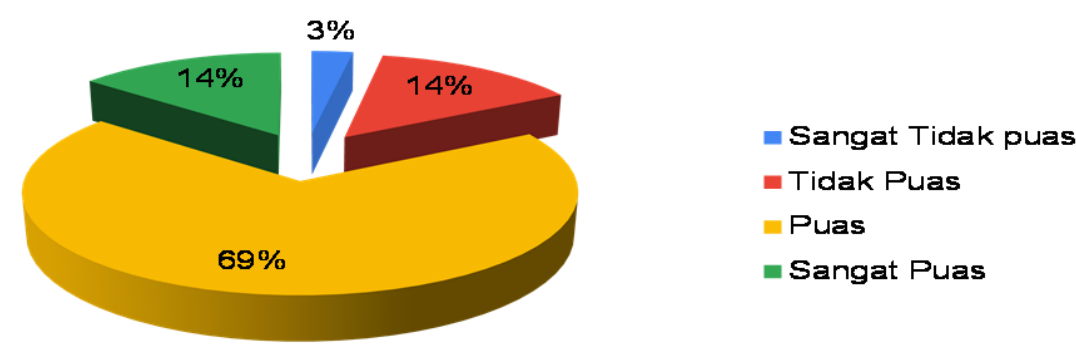

Gambar 1. Hasil Survey Terhadap Kurikulum

\section{Tenaga Pendidik}

Pada aspek tenaga pendidik (Dosen) masih terdapat mahasiswa STKIP Muhammadiyah Bogor yang merasa tidak puas sebesar 5\% ( Tidak Puas), sementara mahasiswa yang sudah merasa puas sebesar 95\% (Puas dan Sangat Puas). Beberapa indikator yang masih harus ditingkatkan pada aspekaspek Tenaga Pendidik berupa: Kedatangan Dosen waktu mengajar (15 Responden), Dosen masih sulit dihubungi untuk keperluan akademik dan bimbingan (15 Responden), kemampuan pembelajaran dosen (18 Responden), dan kualifikasi pendidikan dosen (4 Responden). 


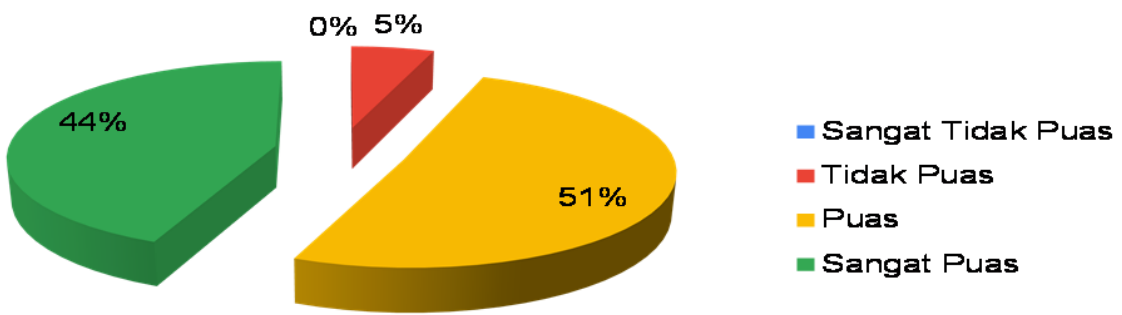

Gambar 2. Hasil Survey Terhadap Tenaga Pendidik

3. Sarana Prasarana

Pada aspek sarana prasarana masih terdapat mahasiswa STKIP Muhammadiyah Bogor yang merasa tidak puas sebesar 63\% (Sangat Tidak Puas dan Tidak Puas), sementara mahasiswa yang sudah merasa puas sebesar 34\% (Puas dan Sangat Puas). Beberapa indikator yang masih perlu mendapat perhatian pada aspek-aspek Sarana Prasarana berupa: Fasilitas Olah Raga, Laboratorium, Parkir Kendaraan (56 Responden), Fasilitas Jaringan Internet dan Media Pembelajaran (48 Responden), Kelengkapan Pendukung Pembelajaran (47 Responden), Ruang Kelas yang nyaman (35 Responden), dan Ketersediaan Tempat Duduk pembelajaran 23 Responden).
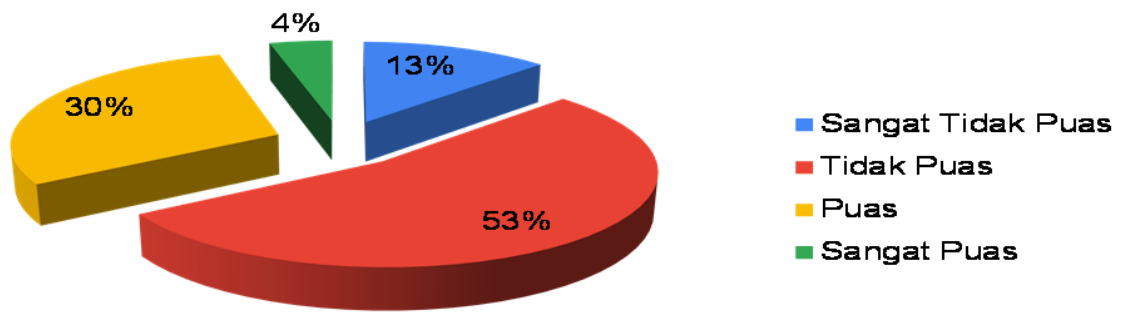

Gambar 3. Hasil Survey Terhadap Sarana Prasarana

\section{Keuangan}

Pada aspek Keuangan masih terdapat mahasiswa STKIP Muhammadiyah Bogor yang merasa tidak puas sebesar 34\% ( Sangat Tidak Puas dan Tidak Puas), sementara mahasiswa yang sudah merasa puas sebesar 66\% (Puas dan Sangat Puas). Beberapa indikator yang masih perlu ditingkatkan pada aspek-aspek Keuangan berupa: Transparansi dan Akuntabilitas Pengelolaan Keuangan (31 Responden), Besaran Biaya Perkuliahan (SPP) (28 Responden), Kebijakan Keuangan dan Sistem Pembayaran Uang Kuliah Yang Meringankan (Masing-masing 24 Responden), dan Sistem Pembayaran Yang Mudah (12 Responden). 


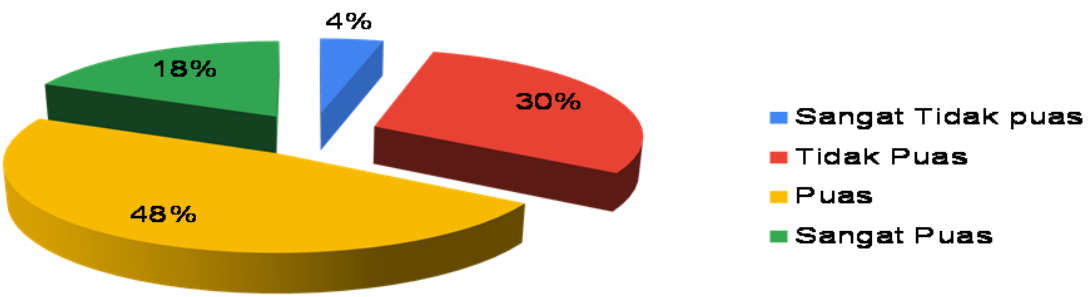

Gambar 4. Hasil Survey Terhadap Pelayanan Keuangan

5. Pelayanan Administrasi Akademik dan Keuangan

Pada aspek Pelayanan Administrasi Akademik dan Keuangan masih terdapat mahasiswa yang merasa tidak puas sebesar 32\% (Sangat Tidak Puas dan Tidak Puas), sementara mahasiswa yang sudah merasa puas sebesar 68\% (Puas dan Sangat Puas). Beberapa indikator yang masih menjadi Pekerjaan Rumah STKIP Muhammadiyah Bogor pada aspek-aspek Keuangan berupa: Kecepatan dalam pelayanan administrasi akademik dan keuangan (33 Responden), Dukungan Sistem Pelayanan Adm Akademik dan Keuangan, Layanan Adm Akademik dan Keuangan Yang Responsif, Layanan Staf Adm Akademik dan Keuangan Yang Komunikatif, Ramah dan Informatif (Masing-masing 26 Responden), Peraturan Kebijakan Adm. Akademik dan Keuangan (33 Responden).
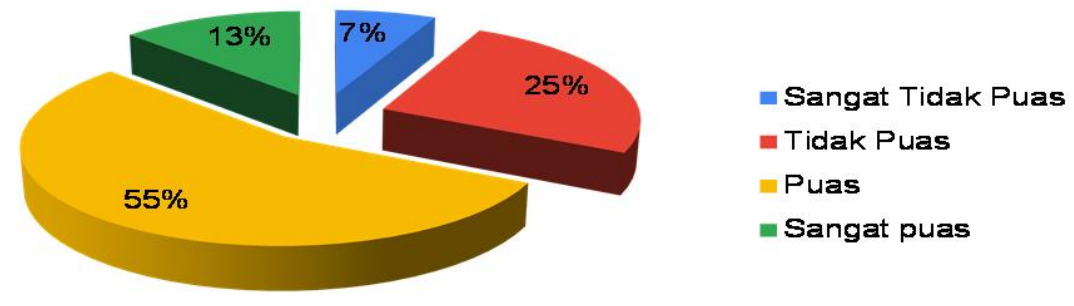

Gambar 5. Hasil Survey Terhadap Pelayanan Administrasi Akademik dan Keuangan

Kepuasaan adalah tingkat keadaan yang dirasakan seseorang yang merupakan hasil dari membandingkan produk yang dirasakan dalam hubungannya dengan harapan seseorang (Arifin dan Rahayu, 2011). Sementara itu, menurut kamus bahasa indnesia Kepuasan dapat diartikan sebagai rasa senang dan kelegaan seseorang dikarenakan mengkomsumsi suatu produk atau jasa untuk mendapatkan pelayanan suatu jasa. Kepuasan adalah perasaan senang atau kecewa seseorang yang muncul setelah membandingkan antara persepsi/kesannya terhadap kinerja (atau hasil) suatu produk dan harapan-harapannya (Asmuji, 2012).

Menurut Parasuraman, Zeithaml, dan Berry (1991) menyatakan bahwa "kualitas pelayanan adalah perbandingan antara pelayanan yang diharapkan konsumen dengan pelayanan yang diterimanya." Atau dengan kata lain apabila pelayanan yang diterima atau dirasakan sesuai dengan yang diharapkan oleh pengguna maka kualitas pelayanan dipersepsikan baik dan memuaskan. Jika jasa atau pelayanan yang diterima melampaui harapan pengguna maka kualitas pelayanan dipersepsikan sebagai 
kualitas ideal. Tetapi sebaliknya jika pelayanan yang diterima lebih rendah dari yang diharapkan maka kualitas pelayanan dipersepsikan buruk. Kualitas pelayanan harus dimulai dari kebutuhan pengguna dan berakhir pada tanggapan pengguna. Tanggapan pengguna terhadap kualitas pelayanan itu sendiri merupakan penilaian menyeluruh terhadap keunggulan suatu pelayanan.

Salah satu model kualitas pelayanan yang populer dan hingga kini banyak dijadikan sebagai acuan dalam riset pemasaran jasa adalah model servqual (service quality) yang dikembangkan oleh Parasuraman, Zeithaml, dan Berry. Servqual yang dijadikan acuan untuk mengukur kualitas pelayanan adalah sebagai berikut: (1) kehandalan (reliability), (2) jaminan (assurance), (3) daya tanggap (responsiveness), (4) empati (empathy) dan (5) bukti langsung (tangibles) (Samosir, 2005).

Oleh karena itu, berdasarkan model yang dikembangkan oleh pasaruman ini, nampak berdasarkan hasil survey yang dilakukan, dimana prosentase terbesar mahasiswa yang menyatakan tidak puas dan sangat tidak puas sebesar 63\% (Sangat Tidak Puas dan Tidak Puas), sementara mahasiswa yang sudah merasa puas sebesar 34\% (Puas dan Sangat Puas). Beberapa indikator yang masih menjadi permasalahan pada aspek-aspek Sarana Prasarana berupa: Fasilitas Olah Raga, Laboratorium, Parkir Kendaraan (56 Responden), Fasilitas Jaringan Internet dan Media Pembelajaran (48 Responden), Kelengkapan Pendukung Pembelajaran (47 Responden), Ruang Kelas yang nyaman (35 Responden), dan Ketersediaan Tempat Duduk pembelajaran 23 Responden). Selanjutnya , pada asepk keuangan $34 \%$ ( Sangat Tidak Puas dan Tidak Puas), sementara mahasiswa yang sudah merasa puas sebesar $66 \%$ (Puas dan Sangat Puas). Pada aspek layanan adminsitrasi akademik dan keuangan menunjukkan sebesar 32\% ( Sangat Tidak Puas dan Tidak Puas), merasa puas sebesar 68\% (Puas dan Sangat Puas). Dan terakhir pada aspek tenaga pendidik tidak puas sebesar 5\% (Tidak Puas), sementara mahasiswa yang sudah merasa puas sebesar 95\% (Puas dan Sangat Puas). Maka berdasarkan model pasaruman dkk, ketidakpuasan mahasiswa atas layanan manajemen STKIP Muhammadiyah Bogor masih dominan pada aspek yang bersifat Tangible (Nampak) berupa sarana prasarana, selanjutnya pada aspek emphaty berupa kebijakan keuangan yang masih belum mempertimbangkan aspirasi mahasiswa, selanjutnya pada aspek Responsive (Daya Tanggap) berupa pelayanan administsi dan keuangan.

\section{Kesimpulan}

Hasil Survey Kepuasan mahasiswa atas layanan manajemen STKIP Muhammadiyah Bogor, masih menunjukkan ketidakpuasan yang cukup tinggi pada indikator yang bersifat tangible berupa ketersediaan Sarana Prasarana dalam mendukung proses pembelajaran. Yang selanjutnya berturut turut pada aspek keuangan (emphaty), layanan administrasi akademik dan keuangan dan tenaga pendidik (Responsive). Maka, berdasarkan hasil survey tersebut diatas, Pimpinan STKIP Muhammadiyah perlu dengan segera menyusun strategi dan implementasi peningkatan layanan manajemen kampus dengan prioritas ditempatkan pada penyediaan ketersediaan sarana prasarana pendidikan yang dapat mendukung pembelajaran lebih optimal.

\section{Daftar Pustaka}

Ali, K., \& Khan, M. A. (2018). Impact of service quality (SQ) on student satisfaction: empirical evidence in the higher education context of emerging economy. AL-ABQARI: Journal of Islamic Social Sciences and Humanities.

Anasrulloh, M. M. (2019). Pengaruh Kualitas Pelayanan Terhadap Kepuasan Konsumen Pada Toko Ritel Dh Mart Tulungagung. Jurnal Pendidikan Ekonomi (Jupeko), 3(2).

Alwi, S. (2012). Manajemen Sumber Daya Manusia Strategi Keunggulan. Kompetitif. Yogyakarta: BPFE

Asmuji. (2012). Manajemen Keperawatan: Konsep dan Aplikasi. Jogjakarta: Ar- Ruzz Media. 
Arifin, Z., \& Rahayu, I. T. (2011). Hubungan antara orientasi religius, locus of control dan psychological well-being mahasiswa fakultas psikologi universitas Islam Negeri Maulana Malik Ibrahim Malang. El-Qudwah, 4(2).

Budiarti, E. M. (2018). Pengaruh Kualitas Layanan, Budaya Akademik, dan Citra Lembaga terhadap Kepuasan Mahasiswa. JMSP (Jurnal Manajemen dan Supervisi Pendidikan), 2(3), 169-178.

Faizan Ali, Yuan Zhou, Kashif Hussain, Pradeep Kumar Nair, Neethiahnanthan Ari Ragavan. (2016). Satisfaction, image and loyalty? A study of international students in Malaysian public universities. Quality Assurance in Education, 24(1).

Hanaysha, J. R., Abdullah, H. H., \& Warokka, A. (2011). Service quality and students' satisfaction at higher learning institutions: The competing dimensions of Malaysian universities' competitiveness. The Journal of Southeast Asian Research, 2011, 1-10.

Indrawan, \& Yaniawati. (2016). Metodologi Penelitian Kuantitatif, Kualitatif, dan Campuran. Bandung; Rineka Aditama.

Kitchroen, K. (2004). Literature review: Service quality in educational institutions. ABAC journal, 24(2).

Mamesah, P. R. (2020). Pengaruh Kualitas Pelayanan Terhadap Kepuasan Pelanggan pada Hotel Lucky Inn Manado. Productivity, 1(1), 46-52.

Parasuraman, Zeithhaml dan Berry (1991). Delivering Service Quality, New York: Free Press.

Phang, S. L. (2013). Factors influencing international students' study destination decision abroad (Master's thesis).

Rahmawati, Yulian Belinda. 2016. Pengaruh Kualitas Pelayanan Terhadap Kepuasan Nasabah Di Pt. Bank Central Asia (Bca) Tbk Cabang Undaan Surabaya. Akrual, 6(1).

Ronitawati, P., Gizi, P. I., Simangunsong, D. W., \& Gizi, P. I. (2018). Analisis Kualitas Makanan dan Kualitas Pelayanan Terhadap Tingkat Kepuasan Konsumen Pada Penyelenggaraan Makanan di Kantin Universitas Esa Unggul. Asal, 45, 0.

Wahab, wirdayani. (2019). Membangun Kepuasan Konsumen Property Melalui Harga Bersaing dan Kualitas Pelayanan pada Perumahan PT. Atlantik Perkasa Abadi Pekanbaru. Ekonomi dan Bisnis, 16(2)

Zurni, Z. S. (2005). Pengaruh Kualitas Pelayanan Terhadap Kepuasan Mahasiswa Menggunakan Perpustakaan USU. Jurnal Studi Perpustakaan dan Informasi, 1(1). 